\title{
Past-Tense Verbs of Futurity in the Holy Quran: A New Text-World Theory Approach
}

\author{
Zakaria Abdelaziz Zakaria Mahmoud ${ }^{1,2 *}$ \\ ${ }^{1}$ University of Salamanca, Department of English Philology, Placentinos 18, 37008 Salamanca, Spain \\ ${ }^{2}$ Beni-Suef University, Faculty of Arts, Department of English Language and Literature, 62511, Beni Suef, Egypt.
}

Corresponding Author: Zakaria Abdelaziz Zakaria Mahmoud, E-mail: id00726480@usal.es

\section{ARTICLE INFO \\ Article history \\ Received: July 05, 2018 \\ Accepted: September 13, 2018 \\ Published: December 01, 2018 \\ Volume: 7 Issue: 7 \\ Advance access: October 2018 \\ Special Issue on Language \& \\ Literature}

Conflicts of interest: None

Funding: None

\begin{abstract}
Since the publication of Paul Werth's (1999) seminal work Text Worlds: Representing Conceptual Space in Discourse, Text World Theory has undergone various modifications and development. In this paper, I attempt to apply the text-world model to two neglected areas of research which are the Arabic language and the Holy Quran. I particularly examine the text-worlds constructed by Arabic past-tense verbs or perfect verbs which express futurity in the Holy Quran. Drawing on my analysis of a number of such Arabic verbs, I argue that the text-world model proposed by Werth and Gavins is not particularly valid for the proposed study of Arabic past-tense verbs or perfect verbs which express futurity in the Holy Quran. Rather, I argue that introducing a new type of world which is a confirmedunrealized text-world to the text-world framework is more effective for the study of the Holy Quran as a sacred and heavenly text. This paper argues further that Gavins' notion of split discourse-world which is used for written communications is not particularly valid for the Holy Quran as a Godly transcript. Instead, the Holy Quran should be dealt with as a type of spoken discourse.
\end{abstract}

Key words: Text World Theory, Arabic Past-Tense Verbs, The Holy Quran, Split discourse-worlds

\section{INTRODUCTION}

Since the publication of Paul Werth's manuscript Text Worlds: Representing Conceptual Space in Discourse in 1999 and his claim that he introduced a framework that can be applicable to all kinds of discourse, the text-world model has been used for analyzing all types of literary and non-literary discourses. The literary genres include poetry (e.g. Gavins, 2007; Lahey, 2006; Gavins and Stockwell, 2012; Giovanelli, 2013), drama (e.g. Gruickshank and Lahey, 2010), narratives (e.g. Gavins, 2000, 2001, 2003, 2005a, 2005b, 2007). The non-literary genres include advertising discourse (e.g. Hidalgo-Downing, 2003 and Gavins, 2007), and political discourse (Chilton, 2004 and Gavins, 2007). This wide-ranging application of Text World Theory leads "in some instances to the proposal of some important modifications to the theory"(Lahey, 2006: 145). For example, Lugea (2016: 9) argues that in spite of Werth's (1999) claim that "the framework is applicable to all text types - spoken and written - his development and description of it is mostly based on literary prose". In her application of the text-world framework to the analysis of Spanish and English spoken narratives, Lugea explains that although Werth presents Text World Theory as a holistic approach to all kinds of discourse, "he makes no mention of how it can be used to analyze a language other than English. Although it was designed in and for English, there is nothing to suggest that Text-World
Theory should be a solely monolingual framework: it is founded on properties which are manifest in all languages" (2016: 9).

In this paper, I agree with Lugea that Text World Theory is mainly a monolingual framework that needs to extend to new linguistic and cultural frameworks such as the Arabic language and the Holy Quran. As is known, the Holy Quran is the word of God. It was transmitted in Arabic, the language of Arabs who, at that time, were famous for their eloquent Arabic language. Hence, the Quran comes to challenge Arabs' fluency and competence in their language and is seen by many as 'a linguistic miracle' (Al-Ali, El-Sharif and Alzyoud, 2016). Nevertheless, most researchers who investigate the Holy Quran from a cognitive linguistic perspective have concentrated on metaphors (see Sharaf Eldin 2015 as an example). Moreover, no text-world theory analysis of the interesting phenomenon of God's usage of Arabic past-tense verbs which portray definite and assured future events at the Day of Judgment has been attempted until now, despite the fact that such verbs flood the glorious Quran. I would argue that the study of those verbs from a text-world perspective will lead to new insights and modifications to the text-world framework.

The aim of this paper, therefore, is twofold. Firstly, it extends the application of Text World Theory to a language rather than English which is the Arabic language. It particu- 
larly focuses on Arabic past-tense verbs which express futurity in the Holy Quran. The analysis will reveal that the textworld framework is not equipped to tackle such issue. Hence, I argue for introducing a new type of world to cope with this problem which is 'a confirmed-unrealized text-world' to the text-world framework. Secondly, the study extends the application of the text-world model to sacred texts represented by the Holy Quran, an area which has not been given due attention from a text-world perspective. I will show that the criteria of split discourse-worlds proposed by Gavins (2007) are not applicable to the Holy Quran as a written form of communication. Instead, the Holy Quran should be dealt with as a type of spoken discourse.

\section{REVIEW OF LITERATURE}

\section{Text World Theory}

Text World Theory is a cognitive discourse theory. The theory was originally founded by Professor Paul Werth in the late 1980s. Werth's thoughts and ideas concerning the text-world framework were published in a series of articles (Werth, 1994, 1995a, 1995b, 1997a, 1997b) and finally were represented in his manuscript which is entitled Text Worlds: Representing Conceptual Space in Discourse. This manuscript was edited, after Werth's death, by Mick Short and published in 1999 (Gavins, 2007; see also Lugea, 2016). Gavins (2007: 7) remarks that the text-world approach "has aroused and sustained the interest of the academic community far beyond Werth's own lifetime".

Werth (1999) bases his approach on the assumption that all of semantics and pragmatics work according to a group of accumulated cognitive domains, i.e. 'mental worlds'. He assumes that 'reality' is an idea which we agree upon but do not have direct access to. For him, the usage of language is bound up with the notion of context since any usage of language must take place in a context of situation. This also assumes the existence of a conceptual level of comprehension which will be created as a result of the interaction between a speaker and hearer(s). Werth (1999) refers to the context in which the discourse takes places as the 'immediate situation' and calls it the discourse world and refers to the conceptual level of comprehension or mental representations that participants of a specific discourse create as the text world. Although the discourse world and the text world are both constructs, the first depends on perception, while the second relies on memory and imagination.

Gavins (2007) also takes the notion of context into consideration when reflecting on the way in which text-worlds are constructed. Her definition of Text World Theory as "a discourse framework" (Gavins, 2007: 8) reflects the point that Text World Theory does not concentrate solely on how a particular text is created but highlights also the importance of contextual elements accompanying the text in its construction and comprehension. A discourse is then a combination of text and context. It represents an event of language or an interaction between different human beings with shared goals. Those human beings are also interacting within a certain space and at a certain time (Werth, 1994). A similar ref- erence is also given by Stockwell (2002): “A world is a language event involving at least two participants, and is the rich and densely textured real-life representation of the combination of text and context" (p. 136).

Werth (1999) shows that a discourse is not only a set of sentences created randomly, but it is an intentional and mutual attempt in which a speaker and hearers interact in order to construct a coherent and meaningful mental representation. A discourse is wilful because it has a purpose. All discourses are created to achieve a certain task or purpose ruled by the principle of communicativeness. Besides, participants should consciously take part in a discourse. Therefore, cases like 'automatic writing' and 'talking in one's sleep' are neglected. It is a mutual endeavour since the recipient's participation is very important. This, then, contradicts the notion that the utterer has the great role in a discourse while the recipient has no role to play except perceiving language passively.

Language, according to Werth (1999: 20) is "a phenomenon bound up with human experience". He claims that endowing linguistics a human feature will ensure its existence in the future. This is the main pillar of Cognitive Linguistics and of the model he calls for. Although it takes the Chomskyan program as its ancestor, it adopts a distinct methodology. It considers discourse rather than sentences as its main data. It also aims at illustrating mental not abstract paradigms (Werth, 1999).

Werth (1999) states that a text or discourse is an interaction between a producer and recipient(s) to set up a 'world' in which its elements are composed appropriately to be understood. This contradicts the generative viewpoint that a text is analyzed as mere a series of sentences considered separately of context and user and then semantically. Werth (1999), on the contrary, refers to the importance of introducing the idea of a 'conceptual background'. He names the conceptual background the text world, borrowing it from the work of Teun Van Dijk (1977). A text world is "a deictic space, defined initially by the discourse itself, and specifically by the deictic and referential elements in it" (Werth, 1999: 20). It is similar to Fauconnier's (1985) idea of 'mental space'. The deictic and referential components are introduced by the discourse. The referential component stimulates some areas of memory called frames. Frames are an organized set of experiences and situations exist in memory as individual elements (see Minsky, 1975, Fillmore, 1982 and 1985). This is why every single person will constitute a different text world from the same discourse. However, every individual will need to follow the rules of the text-world approach in order to build his own text world (Werth, 1999).

Gavins (2007) argues that our previous knowledge and experiences play a vital role in determining the mental representations we create for people. As for Gavins (2007), language is the stimulus that prompts us to create such mental representations. Gavins calls these mental representations 'text-worlds' and claims that they "enable us to conceptualise and understand every piece of language we encounter" (Gavins, 2007: 2). Therefore, the primary base of Text World Theory is structured by cognitive and experiential notions:

Text World Theory is a model of human language processing which is based on the notions of mental repre- 
sentation found in Cognitive Psychology and which shares the experientialist principles of Cognitive Linguistics (Gavins, 2007: 8).

The way in which these text worlds are constructed, their conceptual design, and the way in which human beings utilize them are the main concentration of Text World Theory (Gavins, 2007).

Werth (1999) differentiates between three distinct types of worlds, all of them constituting an element of an event of language: discourse worlds, text worlds and sub-worlds. Although these types of world occupy distinct functions, they look alike. All these worlds contain deictic and referential components to specify a discourse level. Besides, the participants in a current discourse are able to understand the main skeleton of the world they are engaged in by setting up a common ground for the topic under discussion. This topic will definitely be about some 'state of affairs', which can be seen as the information and details composing it. The first identified level of discourse is, then, the discourse world.

Gavins (2007) points out that Text World Theory starts its investigation of communication and the mind at the instantaneous layer of discourse creation; i.e. when there exists somebody to initiate it and another one to perceive it. The purport of this interaction alongside its context constitutes the first level of Text World Theory, namely the discourse world. Gavins (2007) also indicates that the discourse worlds of written texts are split since readers and authors occupy different spatial and temporal environments. Gavins (2007) has also mentioned some reasons that lead to split discourse-worlds. For instance, in telephone conversations, the participants are interacting at the same time but have different locations. In recorded discourse, the participants differ in their temporal as well as physical circumstances. The surrounding components of split discourse worlds hence become of subordinate importance to readers because they will not be perceived simultaneously by the participants. In this case, the text becomes the mere source of information through which the incrementation of knowledge will be available: "The transfer of knowledge from private to public ownership, which forms the primary basis of all discourses, is known as incrementation" (Gavins, 2007: 21).

The second conceptual layer identified by Werth and Gavins is the text world. Werth (1994: 90) refers to text world as a "conceptual space containing all the information necessary to participate in a given discourse". According to Gavins (2007), human beings participating in the discourse world always create mental pictures in their minds of the events dealt with in the discourse. The language introduced in the discourse can thus be conceptualized and comprehended. These mental pictures or representations are referred to as text worlds in Text World Theory terms. Accordingly, the text world level focuses on the conceptualization of events and introduces "a framework through which the precise structure and cognitive effects of individual mental representations can be examined" (Gavins, 2007: 10).

In addition to this, each text-world contains its world-building elements and function-advancing propositions. Werth (1995b: 185) illustrates that "deictic informa- tion, frame knowledge and inferencing combine ... to give the reader a very rich mental representation of the setting" of a literary work. These are described as the world-building elements of the text world and give sense of time, place, character and objects. However, the world-building elements indicate only the background of the text. What constitutes the foreground is what Werth (1995b: 185) terms function-advancing propositions which are described as "the descriptions and events which propel the discourse forward". These function-advancers are erected through language signaling states, actions and processes.

The final layer illustrated by Werth (1999) is sub-worlds or world-switches and modal-worlds in Gavins' (2007) terminology. Once the originating text world is established, countless other worlds are created as a departure from the parameters which set up the initial text world. Such departures constitute the final level of Text World Theory which are named 'sub-worlds' in Werth's (1999) original version of Text World Theory. Discourse, in this way, "is a communicative event which can be represented linguistically as a complex hierarchical structure consisting of different layers" (Hidalgo-Downing, 2000: 222).

\section{Arabic Tenses}

In her contrastive study of the verb systems in English and Arabic, Al-Saleemi (1987) concludes that the Arabic language contains only two tenses, namely the perfect and the imperfect. The perfect tense narrates incidents which occurred and were completed in the past. It is therefore similar to the simple past tense in English. The imperfect tense, on the other hand, reveals and reflects incidents which have not been finished or completed yet. The Arabic present tense or the imperfect form, like that of the English language, "refers to the general present, namely a repeated action, customs, a fact or ability in the present" (Salman, 2010: 20). However, the Arabic perfect and imperfect tenses may have other functions. Since the aim of the present study is not to compare and contrast the similarities and differences between the two language systems, readers can see Al-Saleemi (1987) for a full discussion of this issue. However, Al-Saleemi (1987) has also illustrated that futurity can be expressed in Arabic but there is no future tense form that can perform this function alone. This is because it is necessary to add the particle sa or sawfa [will] to the beginning of the imperfect verb to indicate future events.

In his discussion of how futurity is expressed in the Holy Quran, Al-Khawalda (2000: 70) argues that "the future tense is a controversial issue" if it is dealt with from a linguistic perspective (see also Al-Oliemat, Al-Saikhan and Al-Khawalda, 2018). Al-Khawalda (2000) has discussed three types of expression which can be utilized as indicators of futurity in the Holy Quran. These are: "the use of the present tense form/yaf9alu/("he does/is doing")... the use of the prefix/ sa-/with the present form/sayaf9alu/("he will do"), and the use of the particle/sawfa/with the present form/sawfa yaf9alu/("he will do") (Al-Khawalda, 2000: 71). To my knowledge, no study to date has dealt with the past verbs in the Quran which express futurity from a text-world perspective, 
despite their abundance and multiplicity in the glorious Quran. A subordinate reference to the past tense verbs which reflect futurity in general is only referred to in Salman's (2010) study which investigates the tense shift in Quranic translation into English. Salman (2010: 21) states that "a secondary use of the past tense in Arabic is for future actions of which the speaker is certain".

\section{Data Collection}

The database for this study then is collected from the Holy Quran. The verses which are selected for analysis describe future scenes that will occur at the Day of Judgment. However, all these future scenes are expressed in the past tense or the Arabic perfect form which, as I have shown previously, denote events which happened and ended in the past.

\section{ANALYSIS AND DISCUSSION}

The aim of the analysis and discussion part is to highlight the specific reasons why the text-world framework is unable to explain some perceptual worlds in the Holy Quran, particularly those worlds that are located in a past-time zone and refer to inevitable and certain future events. This part is divided into two interdependent sections. The first argues that the Holy Quran is not a split discourse of communication but is a face-to-face discourse situation occurring between two present participants. Consequently, the Holy Quran is a spoken discourse rather than a written discourse of communication. The second section argues that since readers of the Quranic verses perceive them as telling asserted and unchanged facts, they are not able to use what Gavins calls "world-repair" or "world-replacement" in Text World Theory that readers use to deal with deceptive or illogical representations in certain contexts. Rather, readers of Quran build a confirmed-unrealized text-world in order to understand some of its illogical linguistic contexts. The article therefore attempts to answer the following questions: (1) how does the study of the Holy Quran as a written but also spoken type of religious discourse pose challenges to the text-world framework on both the discourse-world and text-world levels? and (2) how does the new approach proposed in this paper develop world text theory?

\section{The Holy Quran as a Type of Spoken Discourse}

Following Gavins' (2007) terminology, the discourse-world of the Holy Quran, which is a written manuscript, is split, meaning that the participants, God or Allah as the author and readers, are separated in time and space. However, this notion of split discourse-world is problematic if applied to the analysis of the Holy Quran as a written type of communication. This is because God is ubiquitous. He exists in all places and in all times. In spite of the fact that readers of the Holy Quran cannot see God, they are certain that God is seeing them whenever and wherever they are reading the Holy Quran. Besides, readers or reciters feel that they speak directly with God. Moreover, God's interaction with the reader occurs directly and indirectly when a reader shed tears or feels rever- ence and humility in the presence of God when reciting verses from the Holy Quran. Abdel Haleem (2004: xx) remarks that "one stylistic feature that makes the Quran particularly effective is that God speaks directly to people ... and to the Prophet, often using 'We', the first person plural of majesty, to represent Himself'. Consequently, the discourse-world of the Holy Quran cannot be considered as split, but should be seen as a face-to-face discourse situation occurring between two present participants. The discourse-world of the Holy Quran, then, should be dealt with as that of spoken discourses, and not of written communications.

\section{Confirmed-unrealized Text-worlds}

The following verse which comes at the beginning of Surat An-Nahl (The Bees) is analyzed from a text-world perspective:

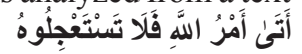

The Command of Allah came, so do not desire to speed it (Surat 16. An-Nahl (The Bees), verse 1).

The verse opens by drawing readers' attention to the temporal boundaries of the initial text-world. The use of the past tense verb أتى "came" positions the Command of Allah in a past-time zone. The enactors in this world are Allah and readers. Because the location and objects of this world are not specified, readers will have to resort to their background knowledge and inferencing capacities to define them. Werth (1999) illustrates that the most essential process of interpretation of text worlds is inferencing. Furthermore, Gavins (2007: 24) claims that "through the process of inferencing, we make use of existing knowledge structures - linguistic, experiential, perceptual and cultural - in order to make sense of new sensory linguistic input". Readers may be aware that the Command of Allah refers to "the Hour of the punishment of disbelivers and polytheists or the Islamic laws or commandments" (Al-Hilali and Khan, 1982: 347), and that it will take place in the Day of Judgment or in the hereafter when God begins to settle account with people concerning their mundane deeds so that people finally enter paradise or hell. Therefore, the location of the originating text-world is the land of the Day of Judgment, while the objects that may exist are paradise and hell. A visual representation of the initial text-world can be shown in Figure 1:

\begin{tabular}{|l|}
\hline \multicolumn{1}{|c|}{ Initial Text-World } \\
\hline world-building elements \\
time: past \\
location: land of the Day of \\
Judgment \\
enactors: God, readers \\
objects: paradise, hell \\
function-advancing propositions \\
The Command of Allah \\
$\downarrow$ \\
came \\
\hline
\end{tabular}

Figure 1. A text-world Analysis of the Initial Text-World 
However, triggered by do not desire to speed it", a negative boulomaic text-world is constructed by the lexical verb "desire" and the negative particle $\vee$ "not". According to Gavins (2007), this world portrays a situation which is not actualized at the moment of its creation. This world is thus stamped with a future-time signature. Readers will also be aware that the Arabic pronoun "it" in نلا نستعجلوه refers to the Command of Allah which had already occurred. The reader hence will have to "repair" (Gavins, 2007) his/ her mental representation and feel that the chronological order of events is illogical. How can we wait for the occurrence of an event which had already happened in the past? Gavins (2007) introduces the notions of world-repair and world-replacement to Text World Theory terminology. Gavins (2007) indicates that some literary works may include deliberate trickery. The reader may find out that the information he has previously known is deceptive. He can realize this trickery at the middle of the literary work. Therefore, he has to repair his mental representation. This is referred to as world-repair in Text World Theory terms. This repair can occur in all discourse-worlds not only in split ones. However, in some cases, the destruction that affects the reader's mental representations may be so enormous that he/she has to replace the previous mental representations with new ones in order to process and continue the discourse at hand. This is known as world-replacement in Text World Theory terminology. Therefore, the reader not only repairs the existing mental pictures but completely replaces them in order to pave the way for a new reading and new worlds.

The Holy Quran is the Book of Allah and it is impossible that it contains information which is not true or illogical. God Himself asserts that $\mathrm{He}$ is completely responsible for protecting the Quran from distortion: "We have sent down the Quran Ourself, and We Ourself will guard it" (Surah Al-Hijr (The Rocky Tract), verse 9; cited in Abdel Haleem, 2004: 162). The only thing to accept is that the past tense expressed by the verb أتى "came" in the above-mentioned verse refers to a future situation which is inevitable and will definitely occur. Because God's power and knowledge are unlimited, His words are certain and accurate. I would argue that the text-world framework is unable to account for such kinds of worlds which are located in a past-time zone and refer to inevitable and certain future events. Hence, I would argue for introducing the notion of "a confirmed-unrealized text-world" to the Text World Theory terminology if we want to guarantee its extension to the application of sacred texts represented by the Holy Quran, an area completely neglected from a text-world perspective. A diagrammatic text-world account of the verse appears in Figure 2 below:

Consider also the other following three examples:

$$
\text { وَحَشَرَنَاهَهُمْ فَلَمْ نُغَادِرْ مِنْهُمْ أَحَدًا }
$$

And We gathered them all together so as to leave no one of them behind (Surah 18. Al-Kahf (The Cave), verse, 47);

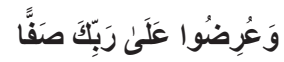

And they sat before your Lord in (lines as) rows (Surah 18. Al-Kahf (The Cave), verse, 48);

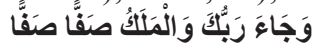

And your Lord came with the angels in rows (surah 89. Al-Fajr (The Dawn), verse 22).

All these verses reflect future scenes that will definitely occur in the Day of Judgment. However, all of them are represented by past-tense verbs. Thus, حشرناهم "gathered them" means "We are going to gather them"; عرضو "sat" means "they are going to sit"; and جاء ربك "your Lord came" means that "your Lord is going to come". What this indicates is that the occurrence of these scenes is definite and inevitable. Therefore, the reader has to construct a confirmed-unrealized mental representation for each one of them in order to understand the verse in its Quranic context.

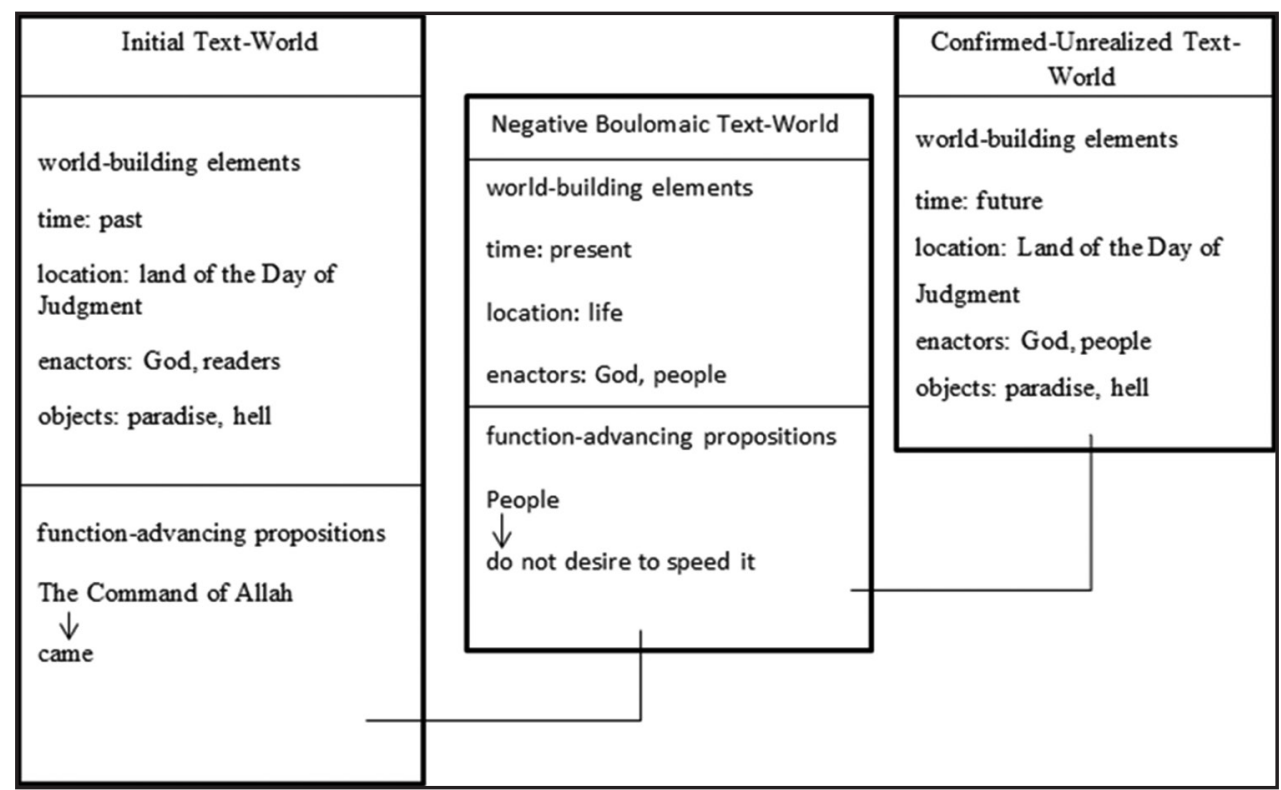

Figure 2. A text-world analysis of the verse "The Command of Allah came, so do not desire to speed it" 


\section{CONCLUSION}

This papers aims at opening new insights when approaching some Arabic verses of the Holy Quran from a text-world perspective. It pursues this objective through combing the text world theory with a confirmed-unrealized text-world in order to overcome two important problems in the textworld framework concerning its application to the Holy Quran as a divine manuscript. The two problems are: first the inability of Gavins' current approach of text-world theory to account for an interesting and miraculous phenomenon in the Holy Quran which is the usage of Arabic past-tense verbs to depict certain future scenes at the Day of Judgment. This paper indicates that a confirmed-unrealized text-world helps readers of certain Quranic verses in accepting the use of past tense to refer to future events through constituting a new mental picture rather than repairing or replacing their mental representations and perceptions. The second problem is that Gavins' notion of split discourse-world is questionable when applying it to a written, yet simultaneously interactive means of communication between readers and God. Thus, the Holy Quran should be studied as a spoken discourse with present interactions between God and readers.

\section{REFERENCES}

Abdel Haleem, M.A. (2004). The Quran. Oxford: Oxford University Press.

Al-Ali, A, El-Sharif, A, \& Alzyoudi, M.S. (2016). The Functions and Linguistic Analysis of Metaphors in the Holy Quran. European Scientific Journal, Vol. 12, No. 14, 164-174.

Al-Hilali, M.T, \& Khan, M.M. (1982 A.D) (1404 A.H). Translation of the meanings of the Noble Qur'an in the English language. King Fahd Complex for the Printing of the Holy Qur'an, Madinah, K.S.A.

Al-Khawalda, M. (2000). The Expression of Futurity in the Arabic and English Languages. In Z. Ibrahim, S. Aydelott, \& N. Kassabgy, (Eds.), Diversity in Language: Contrastive Studies in Arabic and English Theoretical and Applied Linguistics (pp.70-76). The American University in Cairo Press: Cairo. New York.

Al-Oliemat, A, Al-Saikhan, A, \& Al-Khawalda, M. (2018). The Arabic Language in Contrast to English and Italian: Future Tense Revisited. International Journal of Linguistics, Vol.10, No.1, 179-189. https://doi.org/10.5296/ ijl.v10i1.12161

Al-Saleemi, E. (1987). A contrastive study of the verb systems of English and Arabic. Durham theses, Durham University.

Chilton, P. (2004). Analysing Political Discourse. London: Routledge.

Cruickshank, T, \& Lahey, E. (2010). Building the stages of drama: Towards a Text World Theory account of dramatic play-texts. Journal of Literary Semantics 39, 67-91. https://doi.org/10.1515/jlse.2010.004

Fauconnier, G. (1985). Mental Spaces: Aspects of Meaning Construction in Natural Language. MIT Press.
Fillmore, C. (1982). Frame Semantics. In Linguistics in the Morning Calm (pp. 111-137). Hanshin Publishing Company, SEOUL, Korea.

Fillmore, C. (1985). Frames and the semantics of understanding. Quaderni di Semantica 6:2, 222-254.

Gavins, J. (2000). Absurd Tricks with Bicycle Frames in the Text World of The Third Policeman. Nottingham Linguistic Circular 15, 17-33.

Gavins, J. (2001). Text World Theory: A Critical Exposition and Development in Relation to Absurd Prose Fiction, unpublished $\mathrm{PhD}$ thesis, Sheffield Hallam University.

Gavins, J. (2003). Too much blague? An exploration of the text worlds of Donald Barthelme's Snow White. In J. Gavins, \& G. Steen, (Eds.), Cognitive Poetics in Practice (pp. 129-144). London and New York: Routledge. https://doi.org/10.4324/9780203417737

Gavins, J. (2005a). (Re)thinking Modality: A Text World Perspective. Journal of Literary Semantics 34(2), 79-93. https://doi.org/10.1515/jlse.2005.34.2.79

Gavins, J. (2005b). Text World Theory in Literary Practice. In B. Petterson, M. Polvinen, \& H. Veivo (Eds.), Cognition in Literary Interpretation and Practice (pp. 89104). Helsinki: University of Helsinki Press.

Gavins, J. (2007). Text World Theory: An Introduction. Edinburgh: Edinburgh University Press. https://doi. org/10.3366/edinburgh/9780748622993.001.0001

Gavins, J., \& Stockwell, P. (2012). About the heart, where it hurt exactly, and how often. Language and Literature 21(1),33-50.https://doi.org/10.1177/0963947011432052

Giovanelli, M. (2013). Text World Theory and Keat's Poetry: The Cognitive Poetics of Desire, Dreams and Nightmares. Bloomsbury: London.

Hidalgo-Downing, L. (2000). Negation in Discourse: A text world approach to Joseph Heller's Catch-22. Language and Literature, Vol. 9(3), 215-239. https://doi. org/10.1177/096394700000900302

Hidalgo-Downing, L. (2003). Text world creation in advertising discourse. Circulo de Linguistica Aplicada a la Comunicacion 13, 23-44.

Lahey, E. (2006). (Re)thinking world-building: locating the text-worlds of Canadian lyric poetry. Journal of Literary Semantics 35, 145-164.

Lugea, J. (2016). World Building in Spanish and English Spoken Narratives. Bloomsbury: London.

Minsky, M. (1975). A framework for representing knowledge. In P. Winston (Ed.), The Psychology of Computer Vision. McGraw-Hill.

Salman, I. M. (2010). Tense Shift in Quranic Translation into English. Journal of the College of Arts, Vol.1, No.54, 15-46: University of Basrah.

Sharaf Eldin, A.A. (2015). A Cognitive Metaphorical Analysis of Selected Verses in the Glorious Quran. International Journal of Applied Linguistics \& English Literature, Vol. 4, No.2, 193-198.

Stockwell, P. (2002). Cognitive Poetics: An Introduction. London and New York: Routledge.

Van Dijk, T.A. (1977). Text and context: Explorations in the Semantics and Pragmatics of Discourse. London: Longman. 
Werth, P. (1994). Extended Metaphor: A Text World Account. Language and Literature 3 (2), 79-103. https:// doi.org/10.1177/096394709400300201

Werth, P. (1995a). How to Build a World (in a Lot less than Six Days and Using Only What's in your Head). In K. Green (Ed.), New Essays on Deixis: Discourse, Narrative, Literature (pp. 49-80). Amsterdam: Rodopi.

Werth, P. (1995b). World Enough and Time: Deictic Space and the Interpretation of Prose. In P. Verdonk \& J. J. Weber (Eds.), Twentieth Century Fiction: From Text to Context (pp. 181-205). London: Routledge.
Werth, P. (1997a). Conditionality as Cognitive Distance. In A. Athanasiadou, \& R. Dirven (Eds.), On Conditionals Again (pp. 243-271). Amsterdam: Benjamins. https:// doi.org/10.1075/cilt.143.14wer

Werth, P. (1997b). Remote Worlds: The Conceptual Representation of Linguistic World. In J. Nuyts \& E. Pederson (Eds.), Language and Conceptualization (pp. 84-115). Cambridge: Cambridge University Press. https://doi. org/10.1017/CBO9781139086677.004

Werth, P. (1999). Text Worlds: Representing Conceptual Space in Discourse. Longman: London. 